\title{
FACTORS AFFECTING CAREER PREFERENCE OF UNDERGRADUATE STUDENTS
}

\author{
Salman Khatri ${ }^{1}$ and Usman Ali Waraich ${ }^{2}$
}

\begin{abstract}
The object of this research is to identify the study of preferences of undergraduate students on their careers. The method used in this research is quantitative and qualitative. Data collection was collected through online surveys at IoBM university of Karachi. This research gives the explanation about the career preferences that students give during the studies. This research gives explanation on how individuals are handling their work life and how they have selected their careers and what challenges they have faced overall their career life so far. In addition, it extracts a detailed view of job vs business. The results showed that more than half of the students are not properly been through mentoring in early stage which cause issues in future for them. Moreover, the experiential part of the study tries to provide awareness to our government and the parents so that this mistake would not be repeated and students should be allowed to excel in their own choice. On the other hand, this report has guide us the path of doing things right and making the world do things in right way as there are some major concerns to be highlighted at that time otherwise has no importance afterwards like student needs proper time and attention of their parents and guardians at the time of choosing careers, once its locked it has no way back.
\end{abstract}

Keywords: Small \& Medium Sized Enterprises; Social Media Marketing; Transactional Marketing Mechanisms.

\section{INTRODUCTION}

Pakistan is one of the hubs for talent having around 204.73 million population. It faces millions of problems on daily basis and currently is struggling for future as every other country face challenge but with it they have opportunities as well. One of the biggest challenges in Pakistan is unemployment. The Unemployment Rate in Pakistan is around 5.90 percent, as indicated by

\footnotetext{
$1 \& 2$ Institute of Business Management
} 
Trading Economics worldwide large-scale models and examiners' desires. In the long haul, the Pakistan Unemployment Rate is anticipated to incline around 5.90 percent in 2020, as indicated by our econometric model. Because of which it is the center focal point of our examination theme it will distinguish nitty gritty situation in regards to inclination of vocation of students once they are finished with their graduation. It will cover both subjective and quantitative investigation as far as difficulties looked by the understudies after graduation. Because of absence of assets Pakistan faces such a large number of challenges which they can undoubtedly countered on the off chance that they have given a legitimate stage.

Unemployment is characterized by the Bureau of Labor Statistics as individuals who do not have a vocation, have effectively searched for work in the previous a month, and are at present accessible for work. Additionally, individuals who were incidentally laid off and were holding on to be gotten back to that activity are incorporated into the joblessness. In Pakistan, the joblessness rate is extremely high and the significant reason is the wastage of assets on the vast scale. It results in the decline in the salary of individuals. The Unemployment Problem in Pakistan is expanding quickly and because of this, numerous violations are occurring.

The same number of individuals regardless, what the training are inactive in light of the fact that they are not landing any position not by any means the occupations of agents, in normal workplaces or in schools. The state of joblessness is driving towards the discouraging state and the fundamental reason is the poor instruction framework, which is running under the legislature. The guardians spend colossal measure of cash on their youngsters' instruction, however the employments are uncommon and demonstrate indefinable in the present period. Tragically, the administration is not making any move on the joblessness issue in Pakistan since they are occupied in filling their very own pockets with the money of every Pakistani individuals. The causes are infinite, but the major causes of unemployment in Pakistan are given below. 
- $\quad$ Poor education system

- Growth in population

- $\quad$ High age of retirement

- $\quad$ Lack of industries

To counter this problem Pakistan needs to work hard on their educational sector as well as Industrial development sector. One of the basic needs is to provide quality mentoring to the young and energetic generation in school and college students as they need proper counseling from the very basic students and also need to have clear vision along with proper path. In general, under graduates only have two options job or business. A business person is an individual who sets up a business with the intend to make a benefit. This business visionary definition can be somewhat unclear yet in light of current circumstances. A business visionary can be an individual who sets up their first online store as an afterthought or a consultant simply beginning.

The motivation behind why they are viewed as business visionaries, however some deviate, is on the grounds that where a person begins does not end at same place. A business person is somebody who begins a side hustle that can in the end make a full-time, manageable business with workers. Although, the businessperson's significance includes considerably more than being a business or employment maker. Business visionaries are a portion of the world's most dominant transformers. From Elon Musk sending individuals to Mars to Bill Gates and Steve Jobs making PCs part of each family, businesspeople envision the world diversely and the business visionary definition once in a while ever discusses the tremendous effect business visionaries have on the world. Business visionaries see potential outcomes and arrangements where the normal individual just observes irritations and issues. Understanding what a businessperson can enable more individuals to perceive the esteem they add to the world. 


\section{Purpose of the Research}

The above-mentioned background allows as to work on the preference of undergraduate after their degree as this is one of the main reasons where talent lacks. This research will help both the country drivers and the education sectors of the country. Our main purpose of the research is to rectify this issue as much as we can. In addition, this research will identify the detailed view of the difference between Job satisfaction and business which are derived by focus group and questionnaire. The role of educational institutes is the key factor in the development of entrepreneurship.

Having a lot of business schools with a failure in the development of entrepreneurs is a big question mark on the performance of those institutes. Unfortunately, our markets are not yet properly aware of the concepts of branding and other marketing tactics. Besides, people who want to start business complain about the shortage of skilled labor. According to Dawn newspaper article 2016 "university graduates: a case of underutilization" states that; almost half of university graduates are unemployed. Similarly, another main issue is that majority of business schools do not have business incubation centers. No doubt, students learn a lot of things in business institutes but without the touch of market experience all this learning falls in jeopardy. Business incubation centers give students more confidence so that they can turn into entrepreneurs. Moreover, if they do not have resources for incubation centers then they can send their students to small and big firms so they can learn the way to run business. By doing this not only business institutes will produce good business minds, but also it creates good healthy economic environment.

Entrepreneurship also plays the key role in the progress of any country's economy. It works as a backbone for an economy. Countries with the higher GDP shows higher entrepreneurship activities resulting in positive outcomes. If we talk about the entrepreneurial situation in Pakistan, then we have to say it's not satisfactory because of so many reasons like corruption, 
lack of skill developing educational institutes, piracy related laws and most importantly the infrastructure that entrepreneurs demand. Similarly, another main issue is that majority of business schools don't have business incubation centers. Furthermore, mostly our government policies are for the benefits of richer enterprises. On the other hand, small and medium local enterprises are at stakes.

\section{Research Questions}

1. What are under graduated student preferences? Job or business? Why?

2. What are the factors that enforce students' preferences?

3. Why students give preference to job then running business?

\section{Objective of the Study}

To find out the preference of students and the factors inflicting them.

To address the current problem (unemployment) and provide rectification to it.

To find out challenges and issues caused in career selection.

\section{Significance of the Study}

Entrepreneurship plays a vital role in country's economy. It is one of the most important tool that will be used in future for competition among countries and other big platforms. Disappointingly, currently Pakistan is not delivering the desire volume of entrepreneurs needed. Also, students are giving preference to jobs and do not want to go towards selfemployment as there are no support from the government. Some claim that the law and order situation for entrepreneurship is not good in our country our research is directed to create knowledge about how young students of Karachi, Pakistan can be motivated to choose entrepreneurial path and we hope to find the result in positive outcome and highlight the issues faced by young entrepreneurs and which factors help in motivation. 


\section{Limitations}

This research has some limitations which are as follows:

- $\quad$ The sample size for the research is limited. More interviews and surveys should be conducted for the best possible outcomes.

- Interviews will be held with Entrepreneurs in Karachi, Pakistan due to time limitation.

- Accessibility is also an issue due to limited contacts.

- Resistance to change - there is a possibility that we might not receive accurate responses and information.

\section{LITERATURE REVIEW}

The study we are reviewing here evaluates the factors that are influencing and will be helpful for young graduates in taking decision about their careers. Precisely, this review will disclose the factors in detail with the help of recent researches. The factors we are discussing here will guide the students that what profession is suitable for them and what career should they prefer, job or to go for startups or be a businessperson (Entrepreneurs).

Entrepreneurs play an important role in economic growth of the country more over it can be illustrated that entrepreneurs provide job opportunity to others from strategic level to labor. In 21 st century there has been a dramatic shift in the intentions of fresh graduates who are more inclined towards job rather than having a business mind and going for a startup. Young graduates are looking for jobs at initial level and if they failed to do so then they are going for second options. In Asian countries like Pakistan there are number of students who are creative with ideas and they can provide ways to boost the economy. In Pakistan there is a mass up in training and development of entrepreneurs.

\section{Social Impact}


Social environment plays vital role in the grooming of students as well as financial support to make sure that they have to work with devotion rather than thinking about their losses in the startups. Government should start training and development, social awareness programs and create such environment in which their graduates are able to perform better and become pillar of their economy. There is a positive relation between business education and establishing a business. It is identified that the under graduate students are not aware of their skills, and they are lacking in confidence and abilities.

In higher school many students want to become engineers, doctors, pilots. But very few of them achieve their desire destination. Lack of consultancy programs for the students makes it more difficult. Financial backup is another factor for the successful transformation of the students, social environment provides the mental stability for the growth of the students. In European countries most of the undergraduate students are provided with a capital budget to improve their creativity in terms of an entrepreneur. This study is very important to identify the main causes of undergraduate students. The attitude and motivation towards the entrepreneurship is most important factor in entrepreneurship. The entrepreneurial attitude exists in personal and social environmental factor. The entrepreneurs are reducing the poverty and they can help them to improve the economic development. (Dabic, Daim, Bayraktaroglu, Novak, \& Basic, 2012)

\section{Entrepreneurship}

Entrepreneurship is seen by financial experts to be a mix of development and risk taking. At the point when such movement flourishes, high development rates are accomplished just as circumstances offered to all areas of society, including poor people. The last gain from structure development and work is through opening the doors for business innovativeness.

Country like Pakistan there is a lot of misguidance in regards of career counseling and with it there are very few institutes in the main cities that provide career counseling to the young 
energetic generations of the country. Over the past few decades, many researchers have investigated the factors that are influencing job selection decisions; several of them have focused on preferences for certain categories of students, such as accounting students.

The literature on entrepreneurial intentions specifies the significance of self-employment intentions (Fridoline, 2009).

Kristiansen and Indarti (2004) identified the factors of entrepreneurial intentions in Norwegian and Indonesian students. They found high level of entrepreneurial intentions among Indonesian students which was due to economic challenges in Indonesia. While low level was found among Norwegian students, possibly due to high economic remunerations to employees.

According to the recent articles it is also mentioned that job nature also plays a vital role in the career development. It also shows that the attributes is also known as the main stream of the career counseling. According to the survey there is a need of timely review of the students every year to identify their fields of interest.

\section{Gender}

It is also noticeable that female preferences are different as compare to male preferences when it comes to entrepreneurship. Moreover, their intensity of interest also changes with respect to their field of interest mentioning that it is also a fact that students are unable to ensure that what type of career path they choose for the future. Moreover, students that are graduated, their preferences are different from that of under graduate students. Once the student is hired for the job then he or she don't look for opportunities or don't think to start their own business because of the fact that they are satisfied with their jobs and are having the perks of it.

\section{Financial Issues}


Undergraduate students are having more preferences of entrepreneur as compare to other careers path but in it there are risk involve due to financial issues and copy right of the talented ideas which makes the students demotivated and they often end with only job.

\section{Motivation and Career Counseling}

The important part of the research is the identification of student's preferences and work on their goals and their achievements with best practices to offer by the career counseling and to make proper guidance to them. Students who participate in creativity programs are more and highly motivated to become an entrepreneur. This has been investigated that the business education can increase the motivation for individual to become entrepreneurs. Moreover, those who are more risk takers and have high tolerance level are more motivated towards entrepreneurship (Solesvik 2013). According to (Morrison, Breen \& Ali, 2003) the ability of motivation can drive the business according to the desired outcome.

Another study examines the effect of economic conditions and the availability of employment options. On the other hand; when good employment opportunities are available, then societies show negative response towards the individual who wants to become a business person. But in contrast, when employment opportunities are scare then the subjective norm toward entrepreneur becomes positive. That is why people motivate the individual to start his/her career as a businessman (Vinogradov, Kolvereid\& Timoshenko, 2013).

\section{Relationship between Career development and Entrepreneurship}

The career development is also being identified as the major motivator for the study of entrepreneurship. There are variables which influence the intentions towards entrepreneurship which are psychological variable and external environment. (Taormina and Lao 2007). 
Many researchers claim that external environment is easier and more beneficial to recognize the business start-ups. Both variables found the strong important predictor. The psychological variable is also found to be an influencer of potential entrepreneurs and external environment of successful entrepreneurs.

(Dinis, Ferreira, Raposo and Rodrigues 2013) test the entrepreneurial intentions among the secondary students and found the relationship between the psychological characteristics and entrepreneurial intentions. The self-confidence and the need for achievement found to influence the construct. The study concluded that the students carry high level of entrepreneurial functions. As they are more innovative, they have locus of control, need for achievement and also the tolerance to ambiguity.

\section{Opportunity}

(Williams 2008) observe the characteristics of entrepreneurs either they are opportunity-driven or they are necessity-driven. It has been found in the research that both the factors opportunity and necessity are commonly involved in the entrepreneur motives.

(Phillips and Tracey 2007) examined that the recognition of an entrepreneurial opportunity is the skill of the identifying situations and the aspects that which services and products to be introduced or produced. The focus was on opportunity recognition and it has been found that the opportunity recognition is a fundamental to institutional theory of entrepreneurship, which requires the creativity, experience and critical thinking. The institutional theorists have ignored the fact that the students and the institutional entrepreneurs are the opportunity seekers. Similarly, the entrepreneurship capability is the ability to identify a new opportunity and this is also the concept of the explanation of usage of resources and skills required for the entrepreneurial activities. The discussion is mainly about the difference between the entrepreneurship and the institutional entrepreneurship as it has been identified that if the 
institutional entrepreneurs are given opportunities, so they are opportunity seekers and utilize their skills and abilities but unfortunately this aspect is still ignored by the institutional theorists.

Entrepreneurship and business have created a lot of enthusiasm for the last couple of decades not just in the exploratory and scholarly group but also in the political circle. Wanting to become an entrepreneur is called an entrepreneurial intention, such intention within secondary students is enforced by demographic, psychological and behavioral causes (Marques, Ferreira, Gomes \& Rodrigues, 2012). (Jarvis 2016) explored the entrepreneurial identification which influences the individual to recognize opportunity. The recognition indicated as the situations of introducing new goods, services and raw material. Similarly, (Athayde 2012) concluded the young enterpriser attitude towards their entrepreneur. In UK the YE Company organized the young entrepreneur how to start up their business, developed the skills and providing the employment. The small business sources of the economic growth and the most important contribution is that the entrepreneurship creating the jobs and also subsidize in GDP.

The new Opportunities of entrepreneur is exaggerated by two aspects; one is exterior surroundings that opens up by the exterior reasons and other is individual reasons that makes an entrepreneur help in the procedure of making the new business (Shane\& Vankataraman, as cited in Chen, Hung \& yi, 2014; Linan,2008).

The entrepreneurial education increases the entrepreneurship intentions and raises the knowledge and skills of individuals as well. Entrepreneurship intention can be influenced to address various subjective norms and resources which are barriers to create new ventures (Davey et al., 2011; Jones et al., 2011). It has been shown that positive relationship occurs between economics and business education and business creation. As a result, it can be seen 
by the intensive growth of business education in USA which has enhanced the levels of startups and new ventures (Drost, 2010).

\section{Hypothesis}

H1: There is a positive relationship between financial assistance on preferences of students

$\mathrm{H} 2$ : There is a positive relationship between Career counseling on preferences of students

H3: There is a positive relationship between Social Environment on preferences of students

\section{RESEARCH METHODS}

This examination depends on Cross-sectional plan as we needed to discover the effect of reliant and autonomous factors. Independent factors utilized in this examination are "Financial assistance, career counseling, social Environment" while Dependent variable is the factor effecting the Preferences of undergraduate students. Quantitative strategy has been examined the examination.

\section{Population}

The Population is comprised of male and female undergraduate students who examined in various universities of Karachi, Pakistan. The members are focus at age's range beneath the age of 20 to over 30 years of age for finishing the polls.

\section{Sample and Sampling Methods}

A convenience sampling technique was used to collect data from the respondents. After undergoing the survey, respondents were also encouraged to distribute it to their university friends. The total number of responses required for data collected for this particular research is 75 respondents. But we become able to collect the responses of more than 80 respondents we use internet to get the responses and complete our survey and it is supposed to be the best option to collect data. 
Data Collection: Data collection for our research is divided in to two types' i.e. primary and secondary data collection. Primary data was collected through research questions. Secondary data was collected from different articles and consider it as a source of information in this research study. The primary data is collected using questionnaire and secondary data is used as per the support for our research

\section{Instrument Selection}

Poll were utilized as the instruments to accumulate the information as it is the most imperative piece of the examination to gather data from the populace about their musings , their preferences hates in review investigate. Examiners were configuration as Close-finished. The apparatus for study comprised of sorted out survey dependent on legitimate scales.

Likert scales were utilized in the examination. It were begun from Value 1 which speak to Strongly Disagree 2 to concur 3 to impartial 4 to concur and esteem 5 speaking to Strongly Agree.

\section{Variables}

This research is prepared to identify the Impact of financial assistance, career counseling and social environment on students to become an entrepreneur there are two variables in this research study, which are dependent variable and independent variables.

- Dependent Variable: Student's preferences

- Independent Variables: Career counseling, financial assistance and social environment.

\section{Plan of Analysis}

- In this research for the purpose of analysis the data that were gather through survey and to interpret the collected data .SPSS 17.0 used to identify the relationship between the variables and following test were performed i.e., regression, correlation, and some other test were also completed by using SPSS. 


\section{THEORETICAL MODEL}

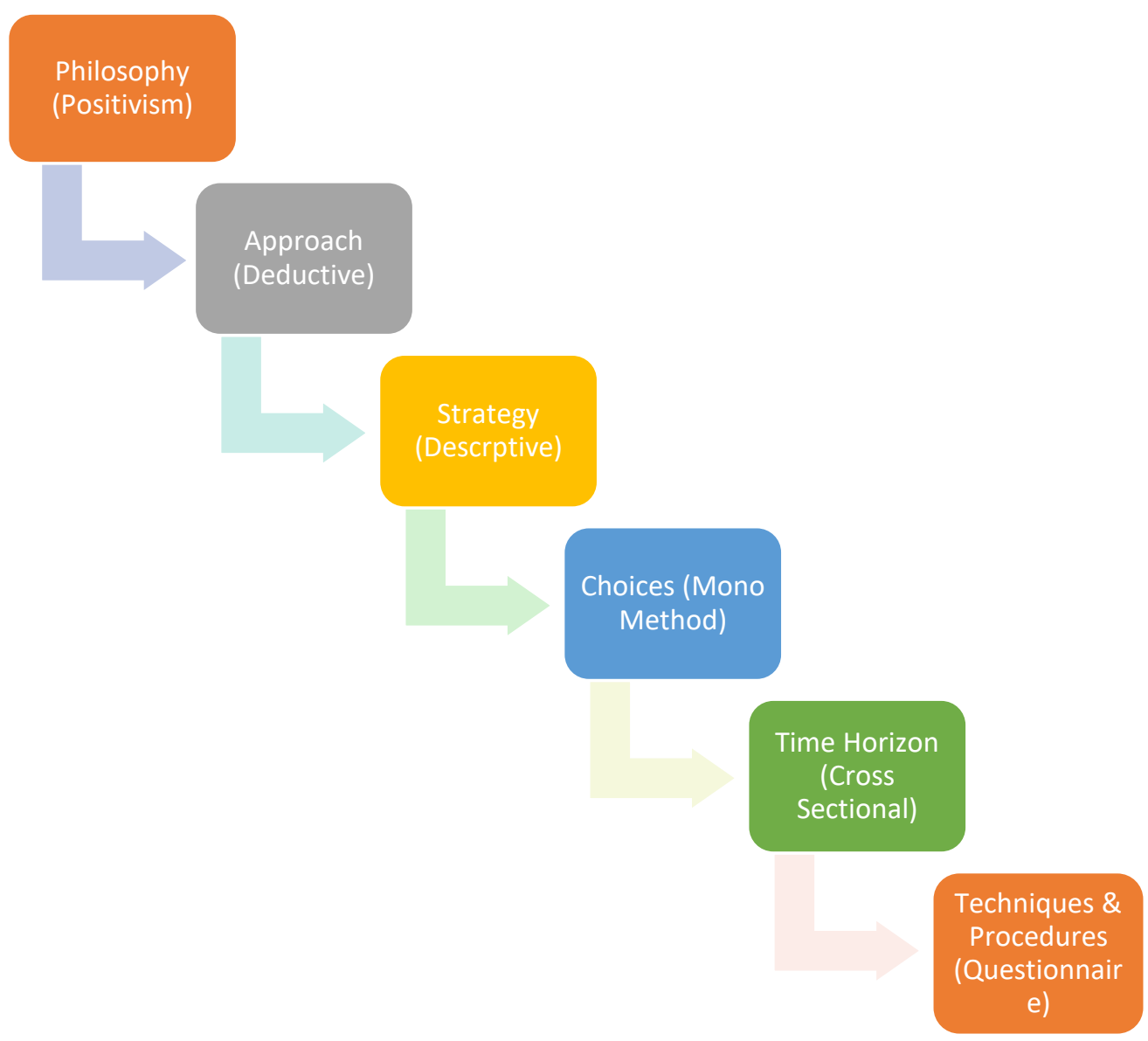

\section{RESULTS AND DISCUSSION}

\section{Results}

Profile of the Respondents:

- Gender: In our sample size $28 \%$ respondents were female and $72 \%$ were male audience.

- Age: $18 \%$ respondents were in age category of below 20 years and 54\% respondents were in age category of between 21 to 30 . While remaining $27 \%$ respondents are in age category of above 30 years.

This research will help universities management to understand the impact of financial assistance, career counseling, and Social environment impact on career preferences of undergraduate students, to clarify out the detail tables are showing the detail. 
Table 1 Statistics

\begin{tabular}{|c|l|l|l|l|}
\hline & Gender & Age & Education \\
\hline Valid & 200 & 200 & 200 \\
\hline Missing & 0 & 0 & 0 \\
\hline Mean & 1.4574 & 2.1064 & 2.8830 \\
\hline Std. Deviation & .50086 & .69511 & 1.58526 \\
\hline
\end{tabular}

Table 2 Gender

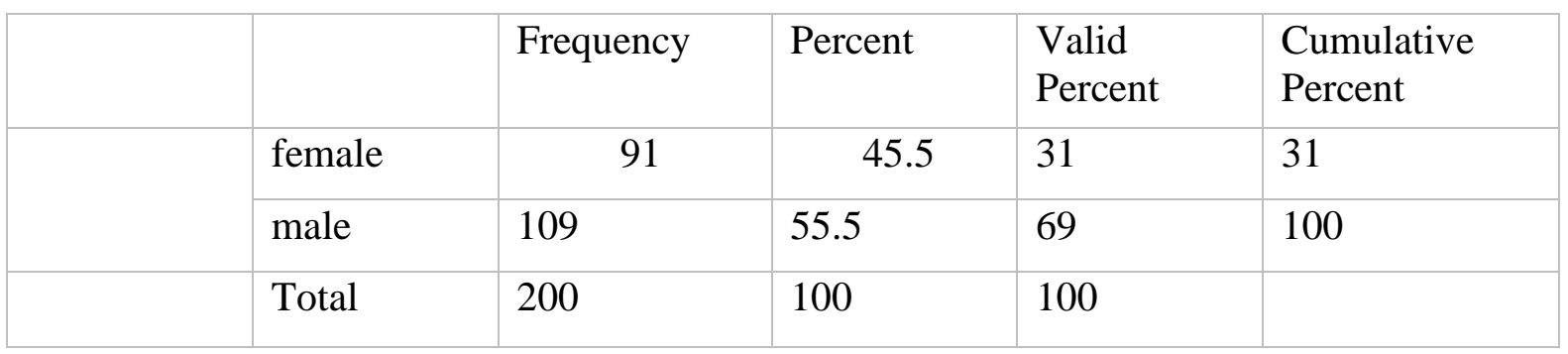

Table 3 Variables

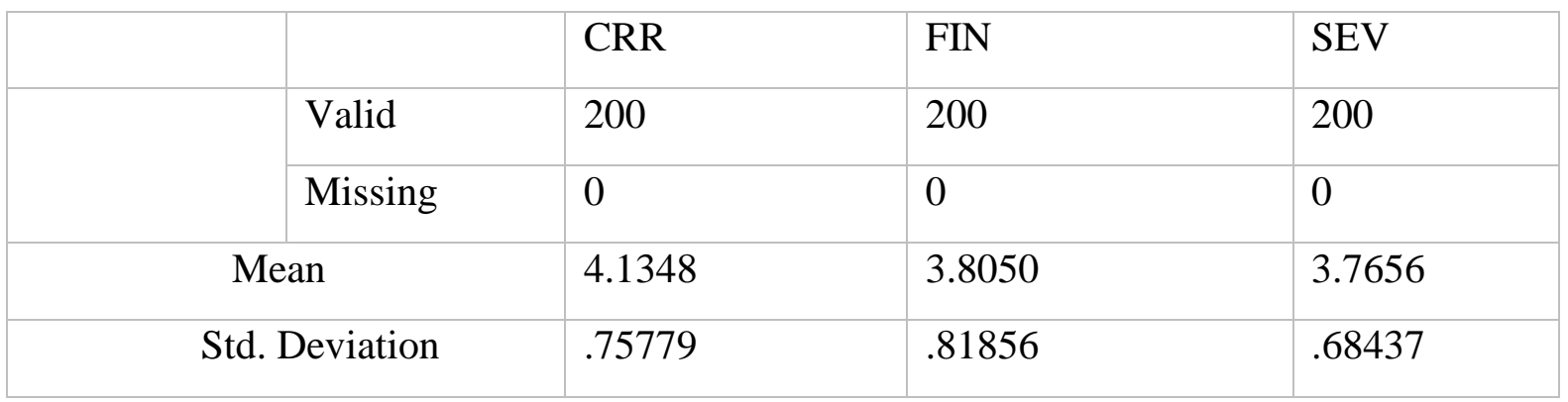

\section{Reliability}

Reliability test was completed on SPSS through reliability testing technique

The Cronbach's Alpha value is 0.701 which is between 0.7 and 0.8 . Following the standard if Cronbach's test value is above or greater than 0.6 it indicates that the internal consistency is acceptable and if Cronbach's Alpha value is between 0.7 and 0.9 it means that consistency of data is good and it this suggested that in the perspective of the preferences the data is reliable. Analysis can be shown in the table below. 
Table 4 Reliability Analysis

\begin{tabular}{|l|l|}
\hline Cronbach's Alpha & N of Items \\
\hline .709 & 11 \\
\hline
\end{tabular}

\section{Impact of Career Counseling, financial assistance and Social Environment on preferences} of undergraduate students.

Analysis is done on the based correlation table shows the Impact of Career Counseling, financial assistance and Social Environment on preferences of undergraduate students. Correlation results Provide Detail that the Career Counseling has .234 \% correlation with financial assistance at $1 \%$ significant level . While Social environment has $.103 \%$ correlation at a significant level of $1 \%$ which indicates that they all are correlated with each other similarly If we check the Financial assistance result it has $0.58 \%$ correlations with social environment at $5 \%$ significant level. Therefore, it indicates that there is a positive correlation between the variables.

Table 5 Correlation

\begin{tabular}{ll|l|l|l}
\hline & & CRR & FIN & SEV \\
\hline \multirow{4}{*}{ CRR } & Pearson Correlation & 1 & $.234^{* *}$ & .103 \\
& Sig. (2-tailed) &. & .001 & .147 \\
& $\mathrm{~N}$ & 200 & 200 & 200 \\
FIN & Pearson Correlation & $.234^{* *}$ & 1 & $.158^{*}$ \\
& Sig. (2-tailed) & .001 & & .025 \\
& $\mathrm{~N}$ & 200 & 200 & 200 \\
SEV & Pearson Correlation & $.103^{* *}$ & $.158^{*}$ & 1 \\
& Sig. (2-tailed) & .147 & .025 & \\
& $\mathrm{~N}$ & 200 & 200 & 200 \\
\hline
\end{tabular}

**. Correlation is significant at the 0.01 level (2-tailed).

\begin{tabular}{|l|l|l|l|l|l|}
\hline Model & $\mathrm{R}$ & R Square & Adjusted R Square & Std. Error of the Estimate & Durbin-Watson \\
\hline 1 & $.464 \mathrm{a}$ & .215 & .203 & .575 & 2.081 \\
\hline
\end{tabular}

a. Predictors: (Constant), SEV, CRR, FIN 
Table 6 Elaborate that the Model summary table which explains that the model we use in this research is fit or not Value of $\mathrm{R}$ indicates and tells that there is a relation between the variables and if there is a high value of $\mathrm{R}$ which indicates that there is a strong relationship and it also indicates that observed and predicted values of the dependent variable. $\mathrm{R}$ square is showing the variation among the dependent variable which is explains by the regression model. Adjusted $\mathrm{R}$ squared shows that the model is goodness of fit and shows the proper evidence by its values if we talk about our research study it has been identified that the value of R square is .215 and adjusted $\mathrm{R}$ square is somehow closer to the value $\mathrm{R}$ square value, which proves and indicates that the model or data is fit.

Durban Watson Also tested on research it shows that if the value is below 2 or equal to 0 indicates that there is a positive correlation among the variables if it is near by 2 it tells that there is a good positive correlation between the variables .In our research Durban Watson test is lie in the range of 2.081 which is equal to 2 it indicates that the test is good and positive.

\section{Analysis of Variance}

ANOVA define the fitness of the model. if the value of $F$ is above 4 so that it means that the model is overall fit. In our test of Anova F value is 3.127 at significant which suggest that that the overall model is slightly not according to the desire result but somehow it is a fit model

\section{Table 7 Anova}

\begin{tabular}{|l|l|l|l|l|l|l|}
\hline & & Sum of Squares & df & Mean Square & F & Sig. \\
\hline 1 & Regression & 2.183 & 3 & .728 & 3.127 & $.029^{\mathrm{b}}$ \\
\hline & Residual & 22.345 & 96 & .233 & & \\
\hline & Total & 24.529 & 99 & & & \\
\hline
\end{tabular}

a. Dependent Variable: DEP

b. Predictors: (Constant), SEV, FIN, CRR

The $t$ test helps to identify that each variable has it own importance in the model. $t$ value greater than 2 or less than 2 as useful predictors of the variable in the model. In our research t test value of Career counseling 2.588 at significant level 0.010 and the Financial assistance has 0.017 at significant level 0.000 . Reject Null hypotheses since the p value is less than 0.1 . 


\section{Table 8 Coefficient}

\begin{tabular}{|c|c|c|c|c|c|}
\hline & Unstandardized Coefficients & & $\begin{array}{l}\text { Standardized } \\
\text { Coefficients }\end{array}$ & & \\
\hline & B & Std. Error & Beta & $\mathrm{t}$ & Sig. \\
\hline (Constant) & 1.755 & 0.220 & & 7.934 & 0.000 \\
\hline CRR & 0.116 & 0.045 & 0.169 & 2.588 & 0.010 \\
\hline FIN & 0.001 & 0.045 & 0.001 & 0.017 & 0.987 \\
\hline SEV & 0.338 & .052 & 0.415 & 6.453 & 0.000 \\
\hline
\end{tabular}

\section{CONCLUSION}

- Career Counseling as significant variable: It is significantly related with the preferences of students; we will accept our Hypothesis H1.

- Financial assistance as significant variable: It is significantly not related with the Preferences of students; hence, we will reject our Hypothesis $\mathrm{H} 2$.

- Social Environment as significant variable: It is significantly related with the Preferences of students; hence, we will accept our Hypothesis H3.

In conclusion, career counseling, financial assistance and social environment considered to be the most important factor that results in greater preference for the students in starting up their own venture. There is the positive relationship between student preference and career counseling, financial assistance and social environment. This report covers one of the biggest issues of Pakistan which is unemployment. The rate is 204.73 million and is increasing every year. Legal bodies has to invest in this sector as it plays a vital role in the development of the country therefore questionnaires were taken place which states that students do want to start business but there are several issues that influence their choice and force them to work for someone else. In past several researches have taken place and they concluded that entrepreneurship needs three main components which are idea generation, financial backup and courage of taking risk. Therefore, students need proper consultation from the very beginning of their studies to excel in future. 


\section{RECOMMENDATIONS}

- The government and financial institutions must provide financial assistance to the students with easy repayment option and no interest resulting in many students after graduating will setup their own venture.

- Students that study in good academic schools still encountered proper mentoring but government schools and private lower scale schools have to work very hard on their student's career counseling.

- Deliver a framework for higher-level skills, attributes and behaviours in entrepreneurship education for art, design and media and a strategy that recognizes and accommodates subject, industry and regional variations.

- To enhance the opportunities for creative industry to contribute to curriculum development and delivery, improve knowledge transfer between industry and higher education and improve opportunities for CPD and life-long learning for creative entrepreneurs.

- $\quad$ To develop coherent policies for entrepreneurship development and entrepreneurship education for art, design and media that draw together the agenda of the range of government agencies

- To strengthen links between higher education institutions' art, design and media departments and courses, creative industry and the wider community - in particular those links demonstrated to enhance effective entrepreneurship education. 


\section{REFERENCES}

Acs, Z. (2006). How is entrepreneurship good for economic growth?. Innovations, 1(1), 97107.

Ajzen, I. (1985). From intentions to actions: A theory of planned behavior. In Action control ( $p p$.

11-39). Springer Berlin Heidelberg.

Ajzen, I. (1991). The theory of planned behavior. Organizational behavior and human decision processes, 50(2), 179-211.

Allport, G. W. (1935). Attitudes.

Altay, Javier Monllor Nezih. "Discovering opportunities in necessity: the inverse creative destruction effect."

Athayde, R. (2012). The impact of enterprise education on attitudes to enterprise in young people: an evaluation study. Education+ training, 54(8/9), 709-726.

Bayon, M. C., Lafuente, E., \& vaillant, Y. (2016). Human capital and the decision to exploit innovative opportunity. Management Decision, 54(7).

Benzing, C., Chu, H. M., \& Kara, O. (2009). Entrepreneurs in Turkey: A factor analysis of motivations, success factors, and problems. Journal of small business management, 47(1), 58-91.

Bhardwaj, B. R., \& Wahi, S. (2013). Determinants of institutional parameters forenhancing entrepreneurial environment in indian context: a model for sustainable growth. International Journal of Entrepreneurship \& Business Environment Perspectives, 2(3), 520.

Block, J., Sandner, P., \& Spiegel, F. (2015). How do risk attitudes differ within the group of entrepreneurs? The role of motivation and procedural utility. Journal of Small Business Management, 53(1), 183-206.

Chrisman, J. J., Chua, J. H., De Massis, A., Frattini, F., \& Wright, M. (2015). The ability and willingness paradox in family firm innovation. Journal of Product Innovation Management, 32(3), 310-318.

Dabic, M., Daim, T., Bayraktaroglu, E., Novak, I., \& Basic, M. (2012). Exploring gender differences in attitudes of university students towards entrepreneurship: an international survey. International Journal of Gender and Entrepreneurship, 4(3), 316-336.

Davidsson, P., \& Honig, B. (2003). The role of social and human capital among nascent entrepreneurs. Journal of business venturing, 18(3), 301-331.

Dietrich, C. (2010). Decision making: factors that influence decision making, heuristics used, and decision outcomes. Student Pulse, 2(02).

Dimov, D. (2010). Nascent entrepreneurs and venture emergence: Opportunity confidence, 
human capital, and early planning. Journal of Management Studies, 47(6), 1123-1153.

Dinis, A., do Paço, A., Ferreira, J., Raposo, M., \& Gouveia Rodrigues, R. (2013). Psychological characteristics and entrepreneurial intentions among secondary students. Education+ Training, 55(8/9), 763-780.

Fayolle, A., Liñán, F., \& Moriano, J. A. (2014). Beyond entrepreneurial intentions: values and motivations in entrepreneurship. International Entrepreneurship and Management Journal, 10(4), 679-689.

Ferreira, J. J., Raposo, M. L., Gouveia Rodrigues, R., Dinis, A., \& do Paço, A. (2012). A model of entrepreneurial intention: An application of the psychological and behavioral approaches. Journal of Small Business and Enterprise Development, 19(3), 424-440.

Hair, J. F., Anderson, R. E., Tatham, R. L., \& William, C. (1998). Black (1998), Multivariate data analysis.

Haus, I., Steinmetz, H., Isidor, R., \& Kabst, R. (2013). Gender effects on entrepreneurial intention: A meta-analytical structural equation model.International Journal of Gender and Entrepreneurship, 5(2), 130-156.

Heuer, A., \& Kolvereid, L. (2014). Education in entrepreneurship and the Theory of Planned Behaviour. European Journal of Training and Development, 38(6), 506-523.

Hörnqvist, M. L., \& Leffler, E. (2013). Principals' Leadership in Nurturing an Entrepreneurial Attitude. In European Conference for Educational Research (ECER).

Hui-Chen, C., Kuen-Hung, T., \& -Yi, P. (2014). The entrepreneurial process: an integrated model. International Entrepreneurship and Management Journal, 10(4), 727-745.

Hytti, U., Stenholm, P., Heinonen, J., \& Seikkula-Leino, J. (2010). Perceived learning outcomes

in entrepreneurship education: The impact of student motivation and team behaviour. Education+Training, 52(8/9), 587-606.

Jarvis, L. C. (2016). Identification, intentions and entrepreneurial opportunities: an integrative processmodel. International Journal of Entrepreneurial Behavior \& Research, 22(2), 182-198.

Kautonen, T., Gelderen, M., \& Fink, M. (2015). Robustness of the theory of planned behavior in predicting entrepreneurial intentions and actions. Entrepreneurship Theory and Practice, 39(3), 655-674.

Kolvereid, L., \& Isaksen, E. (2006). New business start-up and subsequent entry into selfemployment. Journal of Business Venturing, 21(6), 866-885.

Krech, D., \& Crutchfield, R. S. (1948). Theory and problems of social psychology. 
Krueger, N. F., \& Carsrud, A. L. (1993). Entrepreneurial intentions: applying the theory of planned behaviour. Entrepreneurship \& Regional Development,5(4), 315-330.

Krueger, N., \& Dickson, P. R. (1994). How believing in ourselves increases risk taking: Perceived self-efficacy and opportunity recognition. Decision Sciences, 25(3), 385400.

Lee, J. (1996). The motivation of women entrepreneurs in Singapore. Women in Management Review, 11(2), 18-29.

Linan, F. (2008). Skill and value perceptions: how do they affect entrepreneurial intentions? International Entrepreneurship and Management Journal, 4(3), 257-272.

Liñán, F., Rodríguez-Cohard, J. C., \& Rueda-Cantuche, J. M. (2011). Factors affecting entrepreneurial intention levels: a role for education. International entrepreneurship and management Journal, 7(2), 195-218.

Lortie, J., \& Castogiovanni, G. (2015). The theory of planned behavior in entrepreneurship research: what we know and future directions. International Entrepreneurship and Management Journal, 11(4), 935-957.

Maresch, D., Harms, R., Kailer, N., \& Wimmer-Wurm, B. (2016). The impact of entrepreneurship education on the entrepreneurial intention of students in science and engineering versus business studies university programs.Technological forecasting and social change, 104, 172-179.

Marques, C. S., Ferreira, J. J., Gomes, D. N., \& Gouveia Rodrigues, R. (2012). Entrepreneurship education: How psychological, demographic and behavioural factors predict the entrepreneurial intention. Education+ Training,54(8/9), 657-672.

Morrison, A., Breen, J., \& Ali, S. (2003). Small business growth: intention, ability, and opportunity. Journal of small business management, 41(4), 417-425.

Morrison, A., Breen, J., \& Ali, S. (2003). Small business growth: intention, ability, and opportunity. Journal of small business management, 41(4), 417-425.

Nunnally, J. (1978). C.(1978). Psychometric theory.

Phillips, N., \& Tracey, P. (2007). Opportunity recognition, entrepreneurial capabilities and bricolage: connecting institutional theory and entrepreneurship in strategic organization. Strategic organization, 5(3), 313.

Pihie, Z. A. L., \& Bagheri, A. (2013). Self-efficacy and entrepreneurial intention: The mediation effect of self-regulation. Vocations and Learning,6(3), 385-401. 
Rae, D., \& Ruth Woodier-Harris, N. (2013). How does enterprise and entrepreneurship education influence postgraduate students' career intentions in the New Era economy? Education+ Training, 55(8/9), 926-948.

Rosairo, H. R., \& Potts, D. J. (2016). A study on entrepreneurial attitudes of upcountry vegetable

farmers in Sri Lanka. Journal of Agribusiness in Developing and Emerging Economies, 6(1), 39-58.

Sahut, J. M., \& Peris-Ortiz, M. (2014). Small business, innovation, and entrepreneurship. Small Business Economics, 42(4), 663-668.

Sakari Soininen, J., Puumalainen, K., Sjögrén, H., Syrjä, P., \& Durst, S. (2013). Entrepreneurial orientation in small firms-values-attitudes-behavior approach. International Journal of Entrepreneurial Behavior \& Research,19(6), 611-632.

Sarasvathy, S. D., Dew, N., Velamuri, S. R., \& Venkataraman, S. (2003). Three views of entrepreneurial opportunity. In Handbook of entrepreneurship research (pp. 141-160). Springer US.

Schlaegel, C., \& Koenig, M. (2014). Determinants of entrepreneurial intent: a meta-analytic test and integration of competing models. Entrepreneurship Theory and Practice, 38(2), 291-332.

Shane, S. (2012). Reflections on the 2010 AMR decade award: delivering on the promise of entrepreneurship as a field of research. Academy of Management Review, 37(1), 10-20.

Shane, S. A. (2003). A general theory of entrepreneurship: The individual-opportunity nexus. Edward Elgar Publishing.

Sheeran, P., Trafimow, D., Finlay, K. A., \& Norman, P. (2002). Evidence that the type of person

affects the strength of the perceived behavioural control-intention relationship. British Journal of Social Psychology, 41(2), 253-270.

Solesvik, M. Z. (2013). Entrepreneurial motivations and intentions: investigating the role of Education major. Education+ Training, 55(3), 253-271. 